\title{
Non-neurotoxic activity of Malayan krait (Bungarus candidus) venom from Thailand
}

\author{
Mongkon Charoenpitakchai ${ }^{1}$, Kulachet Wiwatwarayos ${ }^{2}$, Nattapon Jaisupa ${ }^{3}$, Muhamad Rusdi Ahmad Rusmili ${ }^{4}$, \\ Supachoke Mangmool ${ }^{5}$, Wayne C. Hodgson ${ }^{6}$, Chetana Ruangpratheep ${ }^{1}$, Lawan Chanhome ${ }^{7}$ \\ and Janeyuth Chaisakul ${ }^{3 *}$
}

\begin{abstract}
Background: Envenoming by kraits (genus Bungarus) is a medically significant issue in South Asia and Southeast Asia. Malayan krait (Bungarus candidus) venom is known to contain highly potent neurotoxins. In recent years, there have been reports on the non-neurotoxic activities of krait venom that include myotoxicity and nephrotoxicity. However, research on such non-neurotoxicity activities of Malayan krait venom is extremely limited. Thus, the aim of the present study was to determine the myotoxic, cytotoxic and nephrotoxic activities of $B$. candidus venoms from northeastern (BC-NE) and southern (BC-S) Thailand in experimentally envenomed rats.

Methods: Rats were administered Malayan krait (BC-NE or BC-S) venom (50 $\mu \mathrm{g} / \mathrm{kg}$, i.m.) or $0.9 \% \mathrm{NaCl}$ solution $(50 \mu \mathrm{L}$, i.m.) into the right hind limb. The animals were sacrificed 3, 6 and $24 \mathrm{~h}$ after venom administration. The right gastrocnemius muscle and both kidneys were collected for histopathological analysis. Blood samples were also taken for determination of creatine kinase (CK) and lactate dehydrogenase (LDH) levels. The human embryonic kidney cell line (HEK-293) was used in a cell proliferation assay to determine cytotoxic activity.
\end{abstract}

Results: Administration of BC-NE or BC-S venom $(50 \mu \mathrm{g} / \mathrm{kg}$, i.m.) caused time-dependent myotoxicity, characterized by an elevation of CK and LDH levels. Histopathological examination of skeletal muscle displayed marked muscle necrosis and myofiber disintegration $24 \mathrm{~h}$ following venom administration. Both Malayan krait venoms also induced extensive renal tubular injury with glomerular and interstitial congestion in rats. BC-NE and BC-S venoms (100-0.2 $\mu \mathrm{g} /$ $\mathrm{mL}$ ) caused concentration-dependent cytotoxicity on the HEK-293 cell line. However, BC-NE venom $\left(\mathrm{IC}_{50}=8 \pm 1 \mu \mathrm{g} /\right.$ $\mathrm{mL}$; at $24 \mathrm{~h}$ incubation; $n=4)$ was found to be significantly more cytotoxic than $\mathrm{BC}-\mathrm{S}$ venom $\left(\mathrm{IC}_{50}=15 \pm 2 \mu \mathrm{g} / \mathrm{mL}\right.$; at $24 \mathrm{~h}$ incubation; $n=4)$. In addition, the PLA $A_{2}$ activity of BC-NE venom was significantly higher than that of BC-S venom.

Conclusions: This study found that Malayan krait venoms from both populations possess myotoxic, cytotoxic and nephrotoxic activities. These findings may aid in clinical diagnosis and treatment of envenomed patients in the future.

Keywords: Krait, Bungarus candidus, Myotoxicity, Nephrotoxicity, Venom, Kidney

\section{Background}

A number of krait species (genus Bungarus) are found throughout the Indian subcontinent (including Sri Lanka and Bangladesh), and in most parts of Southeast Asia and southern China. Malayan krait (Bungarus candidus) is classified into category 1 of medically important venomous snakes in Indonesia (Sumatra, Java and Bali) and Thailand [1]. Previous studies have shown that

\footnotetext{
* Correspondence: janeyuth.cha@pcm.ac.th

${ }^{3}$ Department of Pharmacology, Phramongkutklao College of Medicine,

Bangkok 10400, Thailand

Full list of author information is available at the end of the article
}

phospholipase $\mathrm{A}_{2}\left(\mathrm{PLA}_{2}\right)$ and three-finger toxins (3FTxs) are the major components of Malayan krait venom and responsible for the neurotoxicity following envenoming $[2,3]$. In addition, non-neurotoxic symptoms such as rhabdomyolysis and cardiovascular disturbances (e.g. hypertension and shock) were observed following Malayan krait envenoming in Vietnam [4]. Indeed, the mechanism behind Malayan krait envenoming-induced cardiovascular disturbance was recently demonstrated to involve a combination of vascular mediators and autonomic adaptation [5]. 
Myotoxicity is commonly observed following viper, sea snake and some elapid envenoming, and can be categorized as local or systemic myotoxicity [6-9]. Untreated severe myonecrosis may cause morbidity and mortality. Local myotoxicity affects tissue around the bite site while systemic myotoxicity causes rhabdomyolysis, which is associated with an increase in plasma creatine kinase (CK) and myoglobinuria [9].

Snake venom myotoxins were reported to cause myotoxicity via plasma membrane hydrolysis and depolarization [10]. These toxins have been purified from viper, sea snake, and elapid venoms e.g. Asp49 $\mathrm{PLA}_{2}$ myotoxin was isolated from Bothrops asper venom, PLA-H1 from Hydrophis cyanocinctus venom whereas acanmyotoxins were purified from death adder (Acanthophis sp.) venoms [8, 11-13].

The occurrence of rhabdomyolysis and increased serum CK levels following krait envenoming have been reported in cases involving Vietnamese B. multicinctus and B. candidus. However, these symptoms appeared to be absent in envenomed victims from other locations such as Malaysia and Thailand [14]. This variation may be due to divergence in venom composition and biological activities associated with geographic location $[15,16]$.

Evidence pertaining to myotoxic, cytotoxic and nephrotoxic activities following Southeast Asian krait envenoming is limited. In this study, we aim to determine the myotoxicity, nephrotoxicity and cytotoxicity of venoms collected from northeastern and southern Thailand B. candidus populations. These data will provide additional insights into the geographical differences between these localities and improve the capability of the healthcare workers to recognize and treat B. candidus envenoming.

\section{Methods}

\section{Venom preparation and storage}

Pooled and freeze-dried Malayan krait (B. candidus) venoms from specimens captured in northeast and south of Thailand were obtained from Queen Saovabha Memorial Institute (QSMI), Thai Red Cross Society, Bangkok, Thailand. The venom sample from the northeastern population (BC-NE) consisted of pooled venom from 3 specimens captured in Nakhon Ratchasima whereas, venom from 4 specimens captured in Nakhon $\mathrm{Si}$ Thammarat were pooled for the southern population (BC-S) venom sample. The snakes were milked by directly attaching a microhaematocrit tube to each fang, and the venom transferred to a $1.5 \mathrm{~mL}$ microcentrifuge. Fresh venom was frozen at $-20{ }^{\circ} \mathrm{C}$, freeze-dried and then stored at $-20{ }^{\circ} \mathrm{C}$ prior to use. When required, the venoms were weighed and dissolved in distilled water as a stock solution $(1 \mathrm{mg} / \mathrm{mL})$ and diluted in $0.9 \% \mathrm{NaCl}$ solution. Dissolved solutions were kept on ice during experiments.

Protein quantification by bicinchoninic acid assay (BCA) BCA protein assay kit (Pierce Biotechnology, USA) was used to determine venom protein content. In brief, venoms $(25 \mu \mathrm{L})$ were loaded on to a 96-well plate in triplicate, then $200 \mu \mathrm{L}$ reagent buffer mix was added to each well. The plate was incubated at $37^{\circ} \mathrm{C}$ for $30 \mathrm{~min}$, then read at $562 \mathrm{~nm}$ using a plate reader spectrophotometer (EnSpire ${ }^{\oplus}$ Multimode Plate Reader, PerkinElmer, USA). Protein concentration was determined from the standard curve.

\section{Animal ethics and care}

Male Wistar rats (200-250 g) were purchased from the National Laboratory Animal Centre, Mahidol University, Salaya, Nakhon Pathom, Thailand. Rats were kept in stainless steel containers with access to food and drinking water ad libitum. Approvals for all experimental procedures were granted from the Subcommittee for Multidisciplinary Laboratory and Animal Usage of Phramongkutklao College of Medicine (Documentary Proof of Ethical Clearance no: IRBRTA 1130/2560) and Animal Care and Use Committee of Faculty of Science, Mahidol University (Documentary Proof of Ethical Clearance no: MUSC59-002-335).

\section{Preliminary experiment to determine venom dose}

Preliminary experiments examined the effects of $\mathrm{BC}-\mathrm{S}$ and $\mathrm{BC}-\mathrm{NE}$ venoms, administered to three rats, in intramuscular (i.m.) doses of 50, 100 and $200 \mu \mathrm{g} / \mathrm{kg}$. Venom doses $\geq 100 \mu \mathrm{g} / \mathrm{kg}$ (i.m.) resulted in the death of the rats within 6 h. Subsequently, a dose of $50 \mu \mathrm{g} / \mathrm{kg}$ (i.m.) was chosen for further experiments.

\section{Animal treatments}

The animals were divided into nine groups (administration of $0.9 \% \mathrm{NaCl}$ solution or the two venoms in three different post-injection periods $-3,6$ and 24 h). Rats (4-5 animals per experimental group and control) were anaesthetized with Zoletil $^{\odot}(20 \mathrm{mg} / \mathrm{kg})$ and Xylazine ${ }^{\circ}$ $(5 \mathrm{mg} / \mathrm{kg}$ ) via intraperitoneal (i.p.) route. Venoms were dissolved in $0.9 \% \mathrm{NaCl}$. BC-NE venom (dissolved in $50 \mu \mathrm{L} 0.9 \% \mathrm{NaCl}$ ), BC-S venom (dissolved in $50 \mu \mathrm{L} 0.9 \%$ $\mathrm{NaCl}$ ) or $0.9 \% \mathrm{NaCl}$ (control, $50 \mu \mathrm{L}$ ) was injected into the extensor muscles of the right hind limb.

Following injection of venom or saline, all animals were lightly anaesthetized using Zoletil ${ }^{\odot}(20 \mathrm{mg} / \mathrm{kg}$, i.p.) and Xylazine ${ }^{\odot}(5 \mathrm{mg} / \mathrm{kg}$, i.p.) and sacrificed prior to blood and tissue collection at 3, 6 or $24 \mathrm{~h}$ as per below. 
Blood collection for determination of creatine kinase, lactate dehydrogenase, creatinine, blood urea nitrogen and relevant electrolytes levels

Approximately $0.5 \mathrm{~mL}$ of blood was obtained by cardiac puncture and collected in MiniCollect separation tubes at 3,6 and 24 h post-injection of venom or $0.9 \% \mathrm{NaCl}$. After collection, the samples were centrifuged at $5500 \mathrm{rpm}$ for $10 \mathrm{~min}$. The supernatant was stored at $20{ }^{\circ} \mathrm{C}$ for no longer than $12 \mathrm{~h}$, before determination of creatine kinase (CK) and lactate dehydrogenase (LDH) levels. For early determination of creatinine, blood urea nitrogen (BUN) and relevant electrolytes levels $\left(\mathrm{Na}^{+}, \mathrm{K}^{+}\right.$, $\mathrm{Cl}^{-}$and $\mathrm{HCO}_{3}^{-}$levels), only blood samples at $3 \mathrm{~h}$ postinjection were used. All enzymes and electrolytes levels were detected with liquid assays supplied by Roche Diagnostics Corporation (USA).

\section{Histopathological studies}

The right gastrocnemius muscle and both kidneys were removed and preserved in 10\% formaldehyde before being embedded in paraffin. Embedded samples were cut and stained with hematoxylin-eosin $(\mathrm{H} \& \mathrm{E})$ and/or periodic acid Schiff (PAS). Tissue examination was performed under a light microscope (Olympus BH-2, Olympus Optical Co., Japan). Areas in the slide with pathological changes due to typical myotoxicity and nephrotoxicity were photographed using an Olympus C35 AD camera (Olympus Optical Co., Japan).

\section{Cell culture}

The human embryonic kidney cell line (HEK-293) was purchased from the American Type Culture Collection (ATCC, USA). Cells were grown in a cell culture dish in Dulbecco's modified Eagle's medium supplemented with $10 \%$ fetal calf serum and $1 \%$ penicillin/streptomycin (10\% DMEM), incubated at $37{ }^{\circ} \mathrm{C}$ with $5 \% \mathrm{CO}_{2}$ until $70 \%$ confluence. Cells were lifted using trypsin, and pelleted. HEK-293 cells $(100 \mu \mathrm{L})$ were plated into four 96-well cell culture plates at a density of $2.0 \times 10^{4}$ cells/well. Plates were incubated at $37{ }^{\circ} \mathrm{C}$ in an atmosphere of $5 \% \mathrm{CO}_{2}$.

\section{Cell proliferation assay}

HEK-293 cells were grown overnight. Venom stock solutions were diluted in 10\% DMEM to a final concentration of $0.2-100 \mu \mathrm{g} / \mathrm{mL}$. Venom samples were added to wells in a cell culture plate in quadruplicate $(100 \mu \mathrm{L} /$ well). Culture medium control (cells and medium with no venom) and medium blanks (no cells) were run in parallel. The plates were incubated at $37{ }^{\circ} \mathrm{C}$ with $5 \%$ $\mathrm{CO}_{2}$ for 2, 4 or $24 \mathrm{~h}$. After incubation, the medium was replaced with $200 \mu \mathrm{L}$ of $1 \%$ DMEM and $50 \mu \mathrm{L}$ of MTT solution $(1 \mathrm{mg} / \mathrm{mL})$. The plates were further incubated at $37{ }^{\circ} \mathrm{C}$ with $5 \% \mathrm{CO}_{2}$ for $4 \mathrm{~h}$. The medium was then removed and $100 \mu \mathrm{L}$ of DMSO was added into each well to dissolve formazan crystals. The plate was read using a Tecan microplate reader at $570 \mathrm{~nm}$. The percentage of viable cells was determined as described previously [17].

\section{Determination of PLA ${ }_{2}$ activity}

$\mathrm{PLA}_{2}$ activity of the venoms was determined using a secretory $\mathrm{PLA}_{2}$ colorimetric assay kit (Cayman Chemical, USA, cat no. 765001) as previously described [18].

\section{Chemicals and drugs}

The following chemicals were purchased from SigmaAldrich (USA): MTT, DMSO, eosin, 1\% PAS, hydrochloric acid, Schiff's Leuco-fuchsin solution and Mayer's Haemalum. The following chemicals were purchased from other companies as indicated: BCA Protein Assay Kit (Pierce Biotechnology, USA) and DMEM (Thermo Fisher Scientific, USA).

\section{Data analysis and statistics}

Plasma LDH, CK, plasma BUN, creatinine and electrolyte levels are presented as mean \pm standard deviation (SD). The $95 \%$ confidence interval $(95 \% \mathrm{CI})$ was calculated. For the cell-based assays, sigmoidal growth curves were presented as a percentage of maximal cell growth (\% cell viability) versus log venom concentration and graphed using GraphPad Prism 6 (GraphPad Software Inc., USA). $\mathrm{IC}_{50}$ concentrations were determined to allow for a comparison of venom potency. Student's unpaired $t$-test was performed on venom responses in the presence of venoms in different samples. Multiple comparisons were made using one-way analysis of variance (ANOVA) followed by Bonferroni's multiple comparison test.

\section{Results}

\section{Plasma electrolyte, BUN and creatinine levels following} $3 \mathrm{~h}$ of envenomation

Blood samples were collected following $3 \mathrm{~h}$ of administration of venoms to evaluate their early effects on relevant electrolytes and enzymes. Administration of $\mathrm{BC}-\mathrm{NE}$ or BC-S venom $(50 \mu \mathrm{g} / \mathrm{kg}$, i.m. $)$ significantly increased BUN and potassium levels over a 3-h period when compared with $0.9 \% \mathrm{NaCl}(n=4, p<0.05$, Student's unpaired $t$-test, Table 1). A significant increase in creatinine levels was observed following administration of BC-S venom, but not BC-NE venom. BC-S venom also attenuated plasma $\mathrm{Na}^{+}$concentration when compared to controls $(n=4, p<0.05$, Student's unpaired $t$-test, Table 1$)$. There was no significant change in plasma chloride and bicarbonate levels over the $3 \mathrm{~h}$ period following administration of either venom. 
Table 1 Plasma electrolyte, BUN and creatinine levels 3 h following administration of Malayan krait venoms (50 $\mu \mathrm{g} / \mathrm{kg}$, i.m.) from different populations or saline $(50 \mu \mathrm{L}$, i.m.)

\begin{tabular}{lllllll}
\hline & $\begin{array}{l}\mathrm{BUN} \\
(\mathrm{mg} / \mathrm{dL})\end{array}$ & $\begin{array}{l}\text { Creatinine } \\
(\mathrm{mg} / \mathrm{dL})\end{array}$ & $\begin{array}{l}\mathrm{Na}^{+} \\
(\mathrm{mEq} / \mathrm{L})\end{array}$ & $\begin{array}{l}\mathrm{K}^{+} \\
(\mathrm{mEq} / \mathrm{L})\end{array}$ & $\begin{array}{l}\mathrm{Cl}^{-} \\
(\mathrm{mEq} / \mathrm{L})\end{array}$ & $\begin{array}{l}\mathrm{HCO}_{3}^{-} \\
(\mathrm{mEq} / \mathrm{L})\end{array}$ \\
\hline Saline/Control & $24.7 \pm 1$ & $0.25 \pm 0$ & $147.3 \pm 1$ & $3.8 \pm 0$ & $94.1 \pm 1$ & $22.7 \pm 0$ \\
BC-NE & $40.1 \pm 1^{*}$ & $0.45 \pm 0$ & $135.8 \pm 5$ & $7.9 \pm 1^{*}$ & $90.7 \pm 4$ & $23.7 \pm 0$ \\
BC-S & $44.3 \pm 3^{*}$ & $0.53 \pm 0^{*}$ & $132.5 \pm 4^{*}$ & $10.3 \pm 2^{*}$ & $89.5 \pm 3$ & $18.5 \pm 2$ \\
\hline
\end{tabular}

${ }^{*} p<0.05$ is significantly different from control (Student's unpaired $t$-test), $n=4$

\section{Plasma LDH levels}

BC-S and BC-NE (50 $\mu \mathrm{g} / \mathrm{kg}$, i.m.) venoms caused a timedependent increase in plasma $\mathrm{LDH}$ levels at 3, 6, and $24 \mathrm{~h}$ compared to control. A marked elevation in $\mathrm{LDH}$ levels (> $3500 \mathrm{U} / \mathrm{L}$ ) was seen following venom administration at $24 \mathrm{~h}(n=4-5, p<0.05$, one-way ANOVA, followed by Bonferroni $t$-test, Fig. 1a).

\section{Plasma CK levels}

Venoms $(50 \mu \mathrm{g} / \mathrm{kg}$, i.m.) from both localities significantly increased plasma CK levels 3 and $6 \mathrm{~h}$ after administration compared to control. At $24 \mathrm{~h}$, both venoms significantly increased plasma CK levels $(>2500 \mathrm{U} / \mathrm{L})$ compared to the levels at the 3 and $6 \mathrm{~h}$ time points $(n=$ $4-5, p<0.05$, one-way ANOVA, followed by Bonferroni t-test, Fig. 1b).

\section{Histopathological studies}

Skeletal muscle displayed a minor degree of myofiber disintegration and neutrophilic infiltration 3 and $6 \mathrm{~h}$ following administration of venoms. Both venoms caused generalized muscle necrosis and a high degree of disintegrating muscle fiber with mononuclear infiltrate $24 \mathrm{~h}$ after venom administration (Fig. 2).

Rat kidneys exhibited mild to moderate morphological changes at the 3 and $6 \mathrm{~h}$ time points following BC-NE or BC-S administration (50 $\mu \mathrm{g} / \mathrm{kg}$; i.m.). These changes were characterized by the presence of hyaline cast, dilatation of renal capillary, diffuse or focal glomeruli and/or interstitial vessels congestion (Fig. 3b) and tubular injury (Fig. 3c-e) with loss of brush border. Severe congestion with hemorrhage was observed in glomeruli and interstitial vessels $24 \mathrm{~h}$ following the injection of $\mathrm{BC}-\mathrm{NE}$ venom (50 $\mu \mathrm{g} / \mathrm{kg}$; i.m.) (Fig. 3g). Administration of BC-S venom $(50 \mu \mathrm{g} / \mathrm{kg}$; i.m.) also caused diffuse tubular injury with loss of brush border and the presence of hyaline cast after 6 and $24 \mathrm{~h}$ (Fig. 3f and h, respectively).

Cell viability assay: venom concentration-response curve Incubation of HEK-293 cells with BC-S or BC-NE venoms (100-0.2 $\mu \mathrm{g} / \mathrm{mL})$ caused concentrationdependent inhibition of cell viability (Fig. $4 \mathrm{a}$ and b). The $\mathrm{IC}_{50}$ value of $\mathrm{BC}-\mathrm{NE}$ venom was significantly lower than that of BC-S venom following incubation for $2-24 \mathrm{~h}(p$ $<0.05$, Student's unpaired $t$-test, Table 2) indicating that $\mathrm{BC}-\mathrm{NE}$ venom was significantly more cytotoxic compared to BC-S venom.

\section{Time-dependent effect of venoms incubated with HEK-293} cells

There was no significant difference among the concentration-response curves of BC-NE (100-0.2 $\mu \mathrm{g} /$ $\mathrm{mL}$ ) venom for any time period (2-, 4- and 24-h). However, BC-S venom (100-0.2 $\mu \mathrm{g} / \mathrm{mL})$ caused significant time-dependent cytotoxic effects on the HEK-293 cell line following 4 to $24 \mathrm{~h}$ incubation (Table 2).

\section{Phospholipase $A_{2}$ activity}

$\mathrm{PLA}_{2}$ activity for $\mathrm{BC}-\mathrm{S}$ and $\mathrm{BC}-\mathrm{NE}$ venoms were $573 \pm$ 23 and $1558 \pm 178 \mu \mathrm{mol} / \mathrm{min} / \mathrm{mg}(n=3)$, respectively. The $\mathrm{PLA}_{2}$ activity for the positive control, i.e. bee venom, was $505 \pm 22 \mu \mathrm{mol} / \mathrm{min} / \mathrm{mg}(n=3)$.
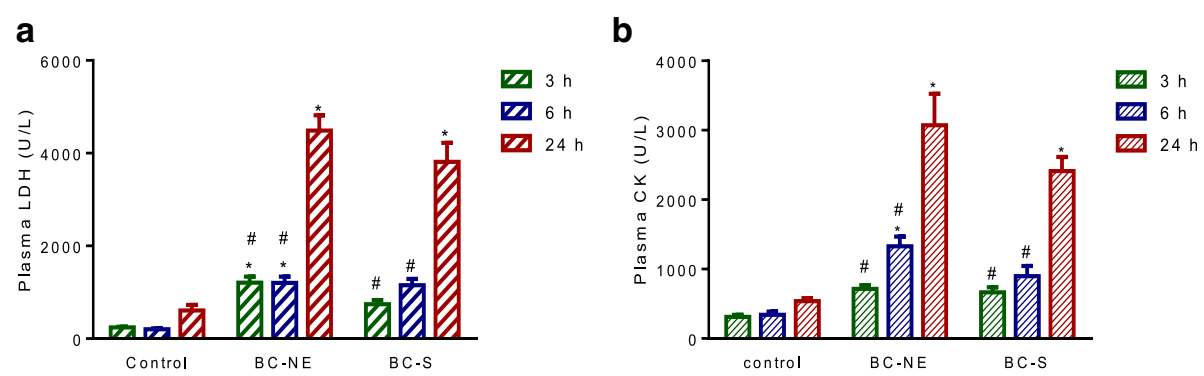

Fig. 1 (a) Plasma lactate dehydrogenase ( $(\mathrm{DH})$ and (b) plasma creatine kinase (CK) levels at 3, 6 and $24 \mathrm{~h}$ following intramuscular (i.m.) administration of saline/control $(50 \mu \mathrm{L}), \mathrm{BC}-\mathrm{S}$ venom $(50 \mu \mathrm{g} / \mathrm{kg})$ or BC-NE venom $(50 \mu \mathrm{g} / \mathrm{kg})(n=4-5) .{ }^{*} p<0.05$ is significantly different from control at the same incubation period (Student's unpaired t-test). ${ }^{*} p<0.05$ is significantly different from $24 \mathrm{~h}$ (one-way ANOVA) 

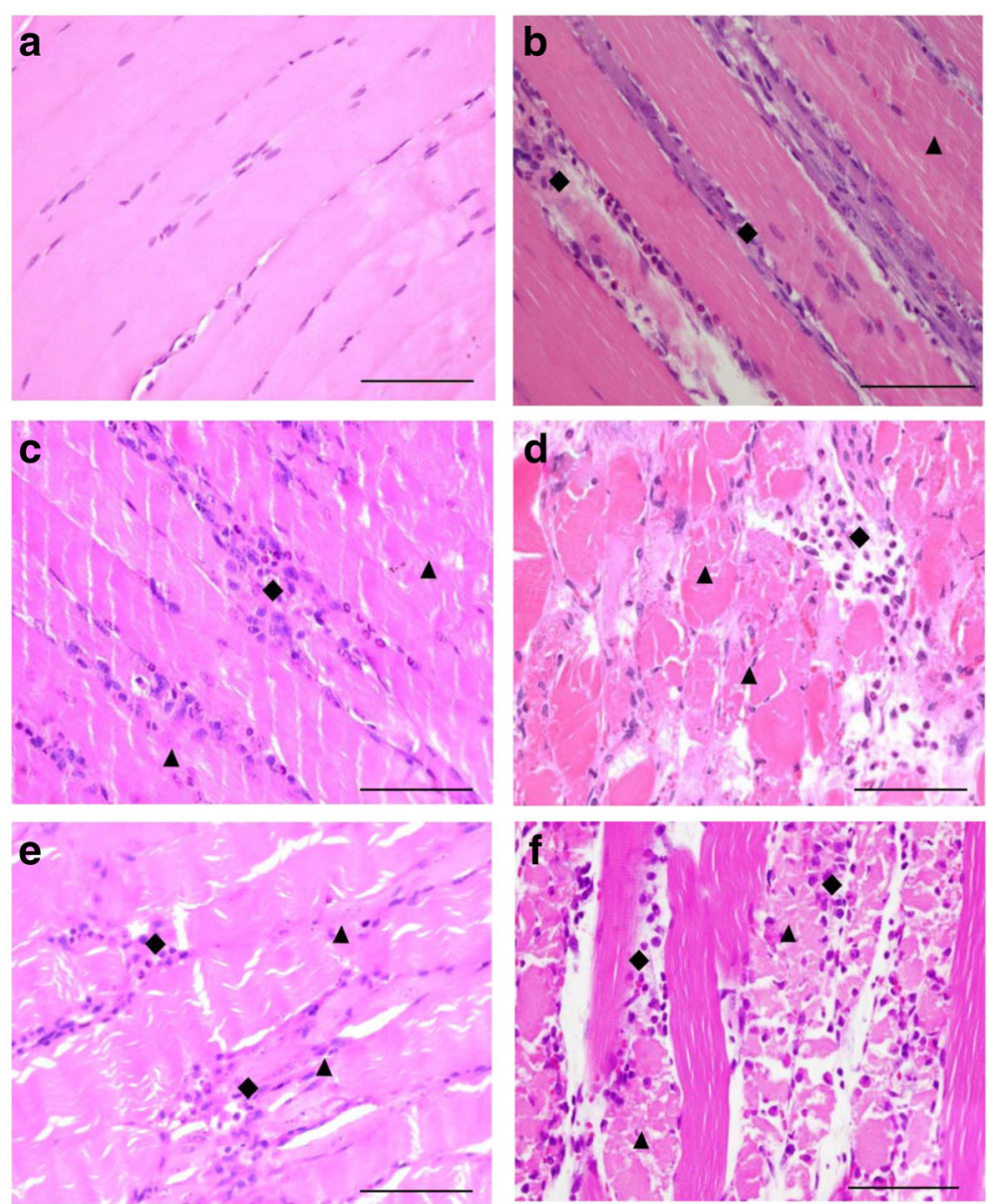

Fig. 2 Morphological changes (H\&E stain, 400× magnification) of rat gastrocnemius muscle following intramuscular (i.m.) administration of (a) vehicle control (normal saline $50 \mu \mathrm{L}$ ), BC-NE (50 $\mathrm{\mu g} / \mathrm{kg}$ ) venom for (b) $3 \mathrm{~h}$, (c) $6 \mathrm{~h}$ and (d) $24 \mathrm{~h}$, or administration of BC-S venom for (e) $6 \mathrm{~h}$ and (f) $24 \mathrm{~h}$. Diamond shapes indicate neutrophilic infiltrate, triangles indicate disintegrating myofibers. Scale $=50 \mu \mathrm{m}$

\section{Discussion}

Systemic myotoxicity is observed following envenoming by sea snake, some viperids and elapids $[7,19,20]$. Clinical outcomes following systemic venom-induced myotoxicity include widespread muscle injury with associated myalgia, elevation of plasma CK level, myoglobinuria and hyperkalemia due to extensive muscle cell damage $[9,21]$. Previous works have shown that systemic envenoming by Bungarus niger could lead to neurotoxic envenoming, myoglobinuria and acute renal failure [22, 23]. B. candidus envenomed patients in Vietnam were reported to display symptoms of rhabdomyolysis and serum CK level elevation [4]. Although severe generalized myalgia and acute renal injury following envenoming by Malayan krait have been anecdotally reported in Thailand $[4,24]$, studies regarding myotoxicity and nephrotoxicity have yet to be carried out.

The determination of CK, LDH and relevant electrolyte concentrations are important to the diagnosis of nephrotoxicity and muscular damage. Our data showed that
Malayan krait venoms from northeastern and southern Thailand caused significant increases in serum CK and $\mathrm{LDH}$ levels following injection. This result is consistent with a Vietnamese case report that showed a rise in CK level in victims after systemic envenoming [4].

In the present study, CK elevation did not reach maximum value within $6 \mathrm{~h}$ as seen for viperid myotoxins or coral snake venoms $[9,25]$. This result is in agreement with a recent study indicating no significant elevation of CK level following Sri Lankan Russell's viper envenoming at the $6 \mathrm{~h}$ time point [19]. The variation in CK levels following venom administration could be attributed to differences in either the pharmacokinetics of venom distribution or method of administration. Indeed, administration of venom via intramuscular or subcutaneous routes may cause a slower rise in venom concentration, resulting in a delayed increase in CK level [6]. In contrast, intravenous administration induced a rapid elevation in CK level due to the $100 \%$ bioavailability of venom compared to intramuscular or subcutaneous ones [6]. 

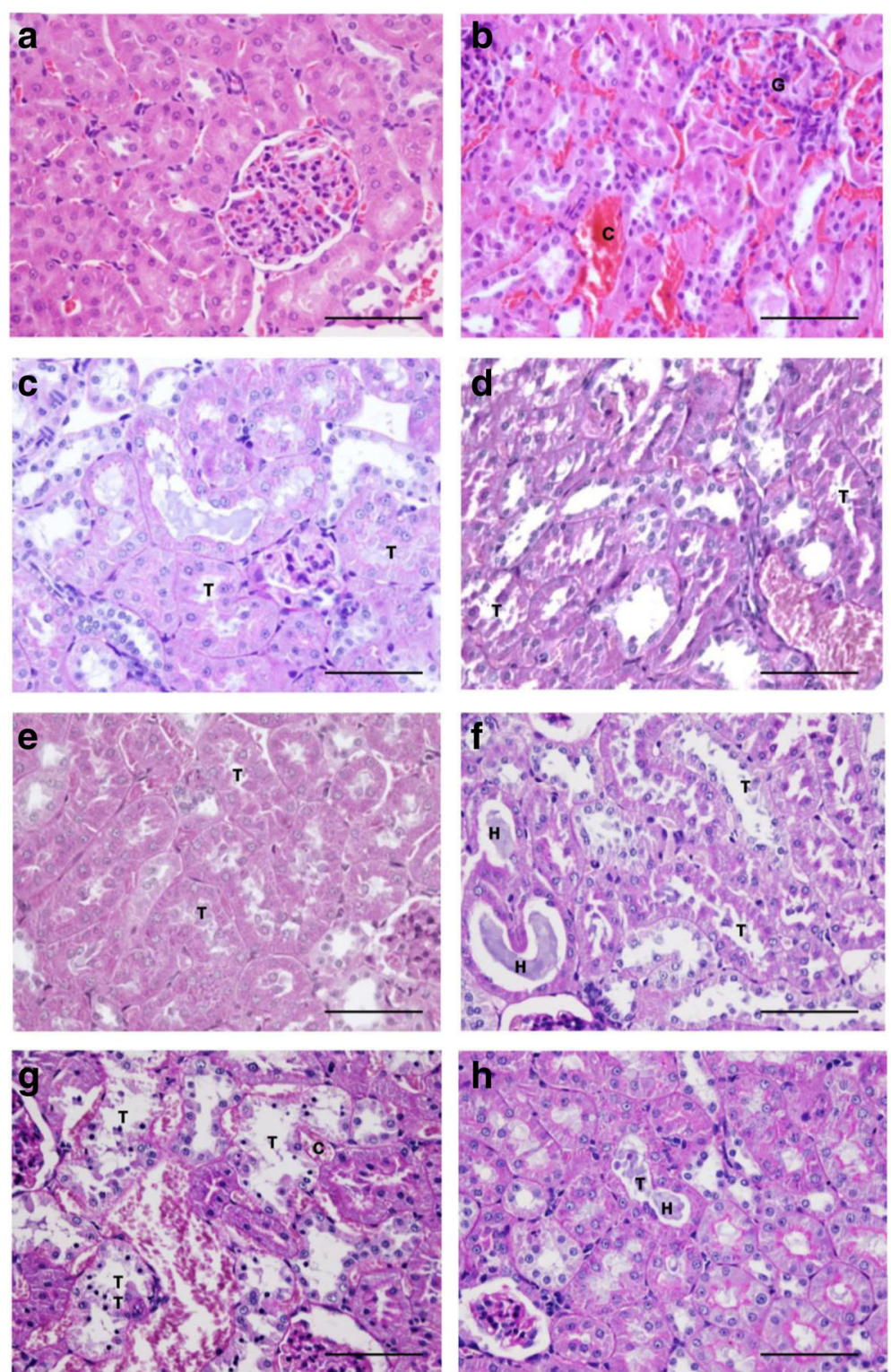

Fig. 3 Morphological changes (H\&E stain; 400x magnification) of rat kidneys following intramuscular administration of (a) vehicle control and (b) BCNE venom for $3 \mathrm{~h}$. Morphological changes (PAS stain; 400x magnification) of rat kidneys following intramuscular (i.m.) administration of BC-NE venom for (c) $3 \mathrm{~h}$, (e) $6 \mathrm{~h}$ and (g) $24 \mathrm{~h}$. Effect of BC-S venom on the morphological changes of rat kidneys following i.m. administration after (d) $3 \mathrm{~h}$, (f) $6 \mathrm{~h}$ and (h) 24 h. Tubular injury is represented by "T". "H" represents hyaline cast. Interstitial congestion is represented by "C". "G" indicates glomerular congestion. Scale $=50 \mu \mathrm{m}$

Early detection of electrolytes is necessary to predict myotoxicity and rhabdomyolysis in envenomed patients. In the present study, injection of Malayan krait venoms from either locality caused elevation of serum BUN, creatinine and potassium levels after $3 \mathrm{~h}$, suggesting that acute kidney injury can be detected in the early stage of envenoming. Interestingly, BC-S venom significantly decreased plasma sodium levels, which suggests hyponatremia. These laboratory data are consistent with previous case reports $[4,20]$. In our study, relevant electrolytes were determined following $3 \mathrm{~h}$ of envenoming. This would be of benefit for the diagnosis of early myotoxicity and nephrotoxicity, as many previous reports displayed the changes in electrolyte in later stages (i.e. after $6 \mathrm{~h}$ of envenoming) $[4,23]$.

Snake venom-induced skeletal muscle damage is characterized by hypercontraction of myofilaments, disruption of the plasma membrane, and tissue necrosis including release of CK [10]. Renal damage can be induced by direct and indirect myotoxic effects of toxins. The indirect effects cause nephrons to be overloaded by degraded proteins, including myoglobin from decayed 

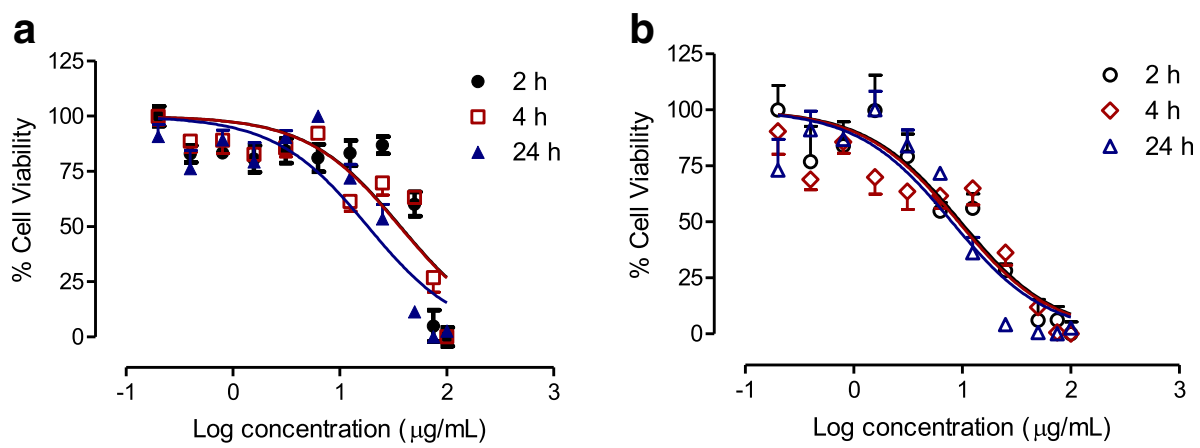

Fig. 4 Sigmoidal growth curves for (a) BC-S and (b) BC-NE venoms (100-0.2 $\mu \mathrm{g} / \mathrm{mL}$ ) after 2, 4 or $24 \mathrm{~h}$ of incubation in HEK-293 cells ( $n=4)$

tissue tubules, which result in secondary acute kidney injury $[8,26,27]$; whereas direct effects cause damage to the kidney cells due to cytotoxicity [28, 29].

In this work, we found that Malayan krait venoms from southern and northeastern populations induced time-dependent myotoxic and nephrotoxic activities. A high degree of myofiber disintegration in skeletal tissues was seen $24 \mathrm{~h}$ following venom administration and this correlates with the increase in plasma CK levels. A lower degree of muscle necrosis was detected as early as $3 \mathrm{~h}$ after venom administration. In the kidneys, the presence of hyaline cast was seen in renal tubules after $3 \mathrm{~h}$ venom administration. Similar renal morphologic changes have also been found in tissues exposed to the venoms of some Russell's vipers, Micrurus species and other terrestrial elapids [25, 30-32].

A range of cytotoxic components in snake venoms may contribute to the severity and development of myotoxicity. Snake myotoxins can be classified into three different groups [33]:

- 'small myotoxins' from rattlesnake venoms such as crotamine from the venom of Crotalus durissus terrificus $[34,35]$;

- 'cardiotoxins', the purified toxins from cobra venom that belong to the 3FTx family [36, 37];

- $\mathrm{PLA}_{2} \mathrm{~s}$, the most abundant myotoxic components in elapid and viperid venoms [38].

Table 2 IC 50 values for BC-S and BC-NE venoms $(n=4)$ on HEK293 cell line

\begin{tabular}{lll}
\hline & \multicolumn{2}{l}{$\mathrm{C}_{50}$ concentration $(\mu \mathrm{g} / \mathrm{mL})$} \\
\hline Incubation time & $\mathrm{BC}-\mathrm{S}$ & $\mathrm{BC}-\mathrm{NE}$ \\
$2 \mathrm{~h}$ & $42 \pm 7$ & $15 \pm 2^{*}$ \\
$4 \mathrm{~h}$ & $26 \pm 2^{\#}$ & $15 \pm 3^{*}$ \\
$24 \mathrm{~h}$ & $15 \pm 2^{\#}$ & $8 \pm 1^{*}$ \\
\hline
\end{tabular}

${ }^{*} p<0.05$ is significantly different from BC-S venom at the same incubation time (Student's unpaired $t$-test)

$\# p<0.05$ is significantly different from $2 \mathrm{~h}$ incubation (one-way ANOVA)
Using proteomic techniques, $3 \mathrm{FTx}$ and $\mathrm{PLA}_{2}$ were found to be the main protein components of Malayan krait venoms [2]. However, Malayan krait myotoxins have not been isolated and characterized. Therefore, the effects of these myotoxins are unknown.

Local muscle necrosis and tissue gangrene are rarely observed following Malayan krait envenoming [4]. However, we found that both venoms displayed cytotoxicity indicating the presence of potent cytotoxins in the venom of this species. The cytotoxic effects of Malayan krait venom were determined using human embryonic kidney (HEK-293) cells. Snake venom cytotoxicity has been demonstrated using various cell lines including rat skeletal muscle, aortic smooth muscle and mammalian kidney cells $[39,40]$. The cell-based assay is a practical model for the determination of cytotoxicity of snake venoms and may be used together with isolated tissue preparations to pharmacologically characterize animal venoms [39]. However, it may not reflect venommediated effects in vivo [41].

The comparison of $\mathrm{IC}_{50}$ at all incubation periods showed that BC-NE venom was significantly more cytotoxic than BC-S venom, which indicates a difference in venom composition and potency. However, the use of different cell lines (i.e. skeletal muscle cells or cardiomyocytes) might indicate different degrees of cytotoxicity [39]. In addition, BC-NE venom was found to have significantly higher $\mathrm{PLA}_{2}$ activity than $\mathrm{BC}-\mathrm{S}$ venom, which may be due to geographical variation.

\section{Conclusions}

In conclusion, we have demonstrated that Malayan krait venoms from two different locations in Thailand display myotoxicity and nephrotoxicity in an animal model with histological evaluation of tissue. We also have shown that $\mathrm{BC}-\mathrm{S}$ and $\mathrm{BC}-\mathrm{NE}$ venoms have significant cytotoxic effects on human embryonic kidney cells. BC-NE venom was found to be more cytotoxic than BC-S venom, but significant differences in myotoxicity and nephrotoxicity were not observed. 


\section{Abbreviations}

3FTx: three-finger toxin; 95\%Cl: 95\% confidence interval; ANOVA: analysis of variance; ATCC: American Type Culture Collection; BCA: bicinchoninic acid assay; BC-NE: Bungarus candidus from northeastern Thailand; BC-S: Bungarus candidus from southern Thailand; BUN: blood urine nitrogen; CK: creatine kinase; DMEM: Dulbecco's modified Eagle's medium; DMSO: dimethyl sulfoxide; h: hour; H\&E: hematoxylin and eosin; i.m.: intramuscular i.p.: intraperitoneal; $I \mathrm{C}_{50}$ : the half maximal inhibitory concentration; LDH: lactate dehydrogenase; MTT: methylthiazolyldiphenyl-tetrazolium bromide; PAS: Periodic acid Schiff; PLA 2 : phospholipases $\mathrm{A}_{2}$; SD: standard deviation

\section{Acknowledgements}

The authors wish to thank the Office of Research Development, Phramongkutklao College of Medicine \& Phramongkutklao Hospital (ORD, PCM \& PMK), Bangkok, Thailand

\section{Funding}

$J C$ received a grant from the National Science and Technology Development

Agency (NSTDA) of the Royal Thai Government Award (SCH-NR2015-382).

\section{Authors' contributions}

MC, KW, NJ and JC performed the experiments. LC provided B. candidus venoms used in this study. MC, KW, MRAR, and JC analyzed the data. WCH, CR, SM and JC developed the idea for the study. MC, KW, MRAR, WCH, and $\mathrm{JC}$ wrote the manuscript. All authors read and approved the final manuscript.

\section{Ethics approval}

Experimental procedures were approved by the Subcommittee for Multidisciplinary Laboratory and Animal Usage of Phramongkutklao College of Medicine (Documentary Proof of Ethical Clearance no: IRBRTA 1130/2560) and Animal Care and Use Committee of Faculty of Science, Mahidol University (Documentary Proof of Ethical Clearance no: MUSC59-002-335).

\section{Consent for publication}

Not applicable.

\section{Competing interests}

The authors declare that they have no competing interests.

\section{Publisher's Note}

Springer Nature remains neutral with regard to jurisdictional claims in published maps and institutional affiliations.

\section{Author details}

'Department of Pathology, Phramongkutklao College of Medicine, Bangkok 10400, Thailand. 'Department of Anatomical Pathology, Army Institute of Pathology, Royal Thai Army Medical Department, Bangkok 10400, Thailand. ${ }^{3}$ Department of Pharmacology, Phramongkutklao College of Medicine, Bangkok 10400, Thailand. ${ }^{4}$ Kulliyyah of Pharmacy, International Islamic University Malaysia, Kuantan Campus, Bandar Indera Mahkota, 25200 Kuantan, Pahang Darul Makmur, Malaysia. ${ }^{5}$ Department of Pharmacology, Faculty of Pharmacy, Mahidol University, Bangkok 10400, Thailand. ' Monash Venom Group, Department of Pharmacology, Biomedical Discovery Institute, Monash University, Clayton, VIC 3800, Australia. ${ }^{7}$ Queen Saovabha Memorial Institute, Thai Red Cross Society, Bangkok 10330, Thailand.

\section{Received: 18 October 2017 Accepted: 2 March 2018}

Published online: 09 March 2018

\section{References}

1. WHO. Venomous snakes of the South-East Asia Region, their venoms and pathophysiology of human envenoming. Guidelines for the management of snake-bites. In: $2^{\text {nd }}$ edition; 2016.

2. Rusmili MR, Yee TT, Mustafa MR, Hodgson WC, Othman I. Proteomic characterization and comparison of Malaysian Bungarus candidus and Bungarus fasciatus venoms. J Proteome. 2014;110:129-44.

3. Nirthanan S, Charpantier E, Gopalakrishnakone P, Gwee MC, Khoo HE, Cheah LS, et al. Neuromuscular effects of candoxin, a novel toxin from the venom of the Malayan krait (Bungarus candidus). Br J Pharmacol. 2003;139(4):832-44.
4. Trinh KX, Khac QL, Trinh LX, Warrell DA. Hyponatraemia, rhabdomyolysis, alterations in blood pressure and persistent mydriasis in patients envenomed by Malayan kraits (Bungarus candidus) in southern Viet Nam. Toxicon. 2010:56(6):1070-5.

5. Chaisakul J, Rusmili MR, Hodgson WC, Hatthachote P, Suwan K, Inchan A, et al. A pharmacological examination of the cardiovascular effects of Malayan krait (Bungarus candidus) venoms. Toxins (Basel). 2017;9(4):pii: E122.

6. Hart AJ, Hodgson WC, O'Leary M, Isbister GK. Pharmacokinetics and pharmacodynamics of the myotoxic venom of Pseudechis australis (Mulga snake) in the anesthetised rat. Clin Toxicol (Phila). 2014;52(6):604-10.

7. Azevedo-Marques MM, Hering SE, Cupo P. Evidence that Crotalus durissus terrificus (south American rattlesnake) envenomation in humans causes myolysis rather than hemolysis. Toxicon. 1987;25(11):1163-8.

8. Ali SA, Alam JM, Abbasi A, Zaidi ZH, Stoeva S, Voelter W. Sea snake Hydrophis cyanocinctus venom. II. Histopathological changes, induced by a myotoxic phospholipase $A_{2}$ (PLA2-H1). Toxicon. 2000;38(5):687-705.

9. Gutierrez JM, Ponce-Soto LA, Marangoni S, Lomonte B. Systemic and local myotoxicity induced by snake venom group II phospholipases $A_{2}$ : comparison between crotoxin, crotoxin B and a Lys49 PLA $A_{2}$ homologue. Toxicon. 2008;51(1):80-92.

10. Melo PA, Burns CF, Blankemeyer JT, Ownby CL. Membrane depolarization is the initial action of crotoxin on isolated murine skeletal muscle. Toxicon. 2004;43(2):111-9.

11. Mora-Obando D, Diaz C, Angulo Y, Gutierrez JM, Lomonte B. Role of enzymatic activity in muscle damage and cytotoxicity induced by Bothrops asper Asp49 phospholipase $A_{2}$ myotoxins: are there additional effector mechanisms involved? PeerJ. 2014;2:e569.

12. Hart AJ, Smith Al, Reeve S, Hodgson WC. Isolation and characterisation of acanmyotoxin-2 and acanmyotoxin-3, myotoxins from the venom of the death adder Acanthophis sp. Seram. Biochem Pharmacol. 2005:70(12):1807-13.

13. Chaisakul J, Parkington HC, Isbister GK, Konstantakopoulos N, Hodgson WC. Differential myotoxic and cytotoxic activities of pre-synaptic neurotoxins from Papuan taipan (Oxyuranus scutellatus) and Irian Jayan death adder (Acanthophis rugosus) venoms. Basic Clin Pharmacol Toxicol. 2013;112(5): 325-34.

14. Warrell DA, Looareesuwan S, White NJ, Theakston RD, Warrell MJ, Kosakarn W, et al. Severe neurotoxic envenoming by the Malayan krait Bungarus candidus (Linnaeus): response to antivenom and anticholinesterase. $\mathrm{Br}$ Med J (Clin Res Ed). 1983;286(6366):678-80.

15. Skejic J, Hodgson WC. Population divergence in venom bioactivities of elapid snake Pseudonaja textilis: role of procoagulant proteins in rapid rodent prey incapacitation. PLoS One. 2013;8(5):e63988.

16. Wickramaratna JC, Fry BG, Hodgson WC. Species-dependent variations in the in vitro myotoxicity of death adder (Acanthophis) venoms. Toxicol Sci. 2003;74(2):352-60.

17. Vongsak B, Mangmool S, Gritsanapan W. Antioxidant activity and induction of mRNA expressions of antioxidant enzymes in HEK-293 cells of Moringa oleifera leaf extract. Planta Med. 2015;81(12-13):1084-9.

18. Chaisakul J, Konstantakopoulos N, Smith Al, Hodgson WC. Isolation and characterisation of P-EPTX-Ap1a and P-EPTX-Ar1a: pre-synaptic neurotoxins from the venom of the northern (Acanthophis praelongus) and Irian Jayan (Acanthophis rugosus) death adders. Biochem Pharmacol. 2010; 80(6):895-902.

19. Silva A, Johnston C, Kuruppu S, Kneisz D, Maduwage K, Kleifeld O, et al. Clinical and pharmacological investigation of myotoxicity in Sri Lankan Russell's viper (Daboia russelii) envenoming. PLoS Negl Trop Dis. 2016;10(12): e0005172.

20. Johnston Cl, Brown SG, O'Leary MA, Currie BJ, Greenberg R, Taylor M, et al. Mulga snake (Pseudechis australis) envenoming: a spectrum of myotoxicity, anticoagulant coagulopathy, haemolysis and the role of early antivenom therapy - Australian snakebite project (ASP-19). Clin Toxicol (Phila). 2013; 51(5):417-24.

21. Denis D, Lamireau T, Llanas B, Bedry R, Fayon M. Rhabdomyolysis in European viper bite. Acta Paediatr. 1998;87(9):1013-5.

22. Pandey DP, Sharma SK, Alirol E, Chappuis F, Kuch U. Fatal neurotoxic envenomation following the bite of a greater black krait (Bungarus niger) in Nepal: a case report. J Venom Anim Toxins incl Trop Dis. 2016;22:19. https:// doi.org/10.1186/s40409-016-0073-8.

23. Faiz A, Ghose A, Ahsan F, Rahman R, Amin R, Hassan MU, et al. The greater black krait (Bungarus niger), a newly recognized cause of neuro-myotoxic snake bite envenoming in Bangladesh. Brain. 2010;133(11):3181-93. 
24. Pochanugool C, Wilde H, Jitapunkul S, Limthongkul S. Spontaneous recovery from severe neurotoxic envenoming by a Malayan krait Bungarus candidus (Linnaeus) in Thailand. Wilderness Environ Med. 1997;8(4):223-5.

25. de Roodt AR, Lago NR, Stock RP. Myotoxicity and nephrotoxicity by Micrurus venoms in experimental envenomation. Toxicon. 2012;59(2):356-64.

26. Ponraj D, Gopalakrishnakone P. Morphological changes induced by a generalized myotoxin (myoglobinuria-inducing toxin) from the venom of Pseudechis australis (king brown snake) in skeletal muscle and kidney of mice. Toxicon. 1995;33(11):1453-67.

27. Sitprija V. Snakebite nephropathy. Nephrology (Carlton). 2006;11(5):442-8.

28. Mebs D, Ownby CL. Myotoxic components of snake venoms: thei biochemical and biological activities. Pharmacol Ther. 1990;48(2):223-36.

29. Gasanov SE, Dagda RK, Rael ED. Snake venom cytotoxins, phospholipase $\mathrm{A}_{2} \mathrm{~S}$, and $\mathrm{Zn}^{2+}$-dependent metalloproteinases: mechanisms of action and pharmacological relevance. J Clin Toxicol. 2014;4(1):1000181.

30. Chaiyabutr N, Vasaruchapong T, Chanhome L, Rungsipipat A, Sitprija V. Acute effect of Russell's viper (Daboia siamensis) venom on renal tubular handling of sodium in isolated rabbit kidney. Asian Biomed. 2014;8(2):195202.

31. Ponraj D, Gopalakrishnakone P. Renal lesions in rhabdomyolysis caused by Pseudechis australis snake myotoxin. Kidney Int. 1997;51(6):1956-69.

32. Ponraj D, Gopalakrishnakone P. Establishment of an animal model for myoglobinuria by use of a myotoxin from Pseudechis australis (king brown snake) venom in mice. Lab Anim Sci. 1996:46(4):393-8.

33. Lomonte B, Rangel J. Snake venom Lys 49 myotoxins: from phospholipases A2 to non-enzymatic membrane disruptors. Toxicon. 2012;60(4):520-30.

34. Oguiura N, Boni-Mitake M, Rádis-Baptista G. New view on crotamine, a small basic polypeptide myotoxin from south American rattlesnake venom. Toxicon. 2005;46(4):363-70.

35. Rádis-Baptista G, Kerkis I. Crotamine, a small basic polypeptide myotoxin from rattlesnake venom with cell-penetrating properties. Curr Pharm Des. 2011;17(38):4351-61.

36. Guardiola O, Andolfi G, Tirone M, lavarone F, Brunelli S, Minchiotti G. Induction of acute skeletal muscle regeneration by cardiotoxin injection. J Vis Exp. 2017;(119)

37. Kini RM, Doley R. Structure, function and evolution of three-finger toxins: mini proteins with multiple targets. Toxicon. 2010;56(6):855-67.

38. Salvador GH, Dos Santos Jl, Lomonte B, Fontes MR. Crystal structure of a phospholipase $\mathrm{A}_{2}$ from Bothrops asper venom: insights into a new putative "myotoxic cluster". Biochimie. 2017;133:95-102.

39. Kalam Y, Isbister GK, Mirtschin P, Hodgson WC, Konstantakopoulos N. Validation of a cell-based assay to differentiate between the cytotoxic effects of elapid snake venoms. J Pharmacol Toxicol Methods. 2011;63(2): $137-42$.

40. Jamunaa A, Vejayan J, Halijah I, Sharifah SH, Ambu S. Cytotoxicity of southeast Asian snake venoms. J Venom Anim Toxins incl Trop Dis. 2012; 18(2):150-6. http://www.scielo.br/scielo.php?script=sci_arttext\&pid=S167891992012000200004

41. Winter KL, Isbister GK, McGowan S, Konstantakopoulos N, Seymour JE, Hodgson WC. A pharmacological and biochemical examination of the geographical variation of Chironex fleckeri venom. Toxicol Lett. 2010;192(3): 419-24.

\section{Submit your next manuscript to BioMed Central and we will help you at every step:}

- We accept pre-submission inquiries

- Our selector tool helps you to find the most relevant journal

- We provide round the clock customer support

- Convenient online submission

- Thorough peer review

- Inclusion in PubMed and all major indexing services

- Maximum visibility for your research

Submit your manuscript at www.biomedcentral.com/submit

) Biomed Central 